\title{
Soil physical properties under a 'Tanzânia' grass pasture fertilized with mineral nitrogen or intercropped with stylosanthes
}

\author{
Camila Jorge Bernabé Ferreira ${ }^{(1)}$, Cássio Antonio Tormena ${ }^{(1)}$, Ulysses Cecato(1), \\ Hélio Henrique Soares Franco(1), Wagner Henrique Moreira ${ }^{(2)}$, Sandra Galbeiro ${ }^{(3)}$ and Ossival Lolato Ribeiro ${ }^{(4)}$
}

\begin{abstract}
(1)Universidade Estadual de Maringá, Avenida Colombo, no5.790, CEP 87020-900 Maringá, PR, Brazil. E-mail: camilajbferreira@gmail.com, catormena@uem.br, ulyssescecato@gmail.com, hhsfranco@hotmail.com ${ }^{(2)}$ Instituto Federal de Educação, Ciência e Tecnologia de Mato Grosso do Sul, Rodovia MS-473, KM 23, s/no, Fazenda Santa Bárbara, CEP 79750-000 Nova Andradina, MS, Brazil. E-mail: wagner.moreira@ifms.edu.br ${ }^{(3)}$ Universidade Estadual de Londrina, Acesso Jardim Bandeirantes, CEP 86057970 Londrina PR, Brazil. E-mail: sgalbeiro@gmail.com ${ }^{(4)}$ Universidade Federal da Bahia, Avenida Adhemar de Barros, № 500, CEP 40170110 Salvador, BA, Brazil. E-mail: ossribeiro@hotmail.com
\end{abstract}

\begin{abstract}
The objective of this work was to evaluate the physical properties of a soil with a 'Tanzânia' grass (Megathyrsus maximus) pasture fertilized with mineral nitrogen or intercropped with the legume 'Campo Grande' (Stylosanthes spp.), and subjected to continuous grazing and variable stocking rate, in a three-year chronosequence. The treatments were: 'Tanzânia' grass and Stylosanthes; and 'Tanzânia' grass fertilized with 75,150 , and $225 \mathrm{~kg} \mathrm{ha}^{-1} \mathrm{~N}$ per year. The experiment was carried out in an Oxisol, in a randomized complete block design with three replicates, in split plots divided according to time (first, second, and third experimental years). The following soil properties were assessed annually: soil bulk density, porosity in the soil macropore domain, soil water and air storage capacity, and soil penetration resistance. After three years, the highest animal stocking rate due to increased forage yield did not affect the soil physical conditions. The intercrop of 'Tanzânia' grass with the legume shows values of soil water and air storage capacity close to the ideal ones $(0.66$ and 0.34 , respectively). After the second experimental year, there is a decrease in the penetration resistance values, which are inferior to the critical limit of 2,500 $\mathrm{kPa}$. The intercropping of 'Tanzânia' grass with stylosanthes 'Campo Grande' can be a remarkable alternative for the maintenance and improvement of soil physical conditions.
\end{abstract}

Index terms: Panicum maximum, Stylosanthes, soil penetration resistance, stocking rate.

\section{Propriedades físicas de solo sob pastagem de capim-tanzânia adubada com nitrogênio mineral ou consorciada com estilosantes}

\begin{abstract}
Resumo - O objetivo deste trabalho foi avaliar as propriedades físicas de um solo com pastagem de capimtanzânia (Megathyrsus maximus) fertilizado com nitrogênio mineral ou consorciado com a leguminosa estilosantes 'Campo Grande' (Stylosanthes spp.), submetido a pastejo contínuo e à taxa de lotação variável, em uma cronossequência de três anos. Os tratamentos foram: capim-tanzânia e estilosantes; e capim-tanzânia adubado com 75, 150 e $225 \mathrm{~kg} \mathrm{ha}^{-1}$ de $\mathrm{N}$ por ano. O experimento foi realizado em Latossolo Vermelho distrófico, em blocos ao acaso com três repetições, com parcelas subdivididas no tempo (primeiro, segundo e terceiro anos experimentais). Foram avaliadas, anualmente, as seguintes propriedades do solo: densidade do solo, porosidade no domínio dos macroporos, capacidade de armazenamento de água e ar do solo e resistência do solo à penetração. Após três anos, a maior taxa de lotação animal, em razão do aumento da produção de forragem, não afetou as condições físicas do solo. O consórcio de pastagem de capim-tanzânia com a leguminosa apresenta valores de capacidade de armazenamento de água e ar do solo próximos aos ideais $(0,66$ e 0,34, respectivamente). Após o segundo ano experimental, ocorre decréscimo dos valores de resistência do solo à penetração, que ficam abaixo do limite crítico de $2.500 \mathrm{kPa}$. O consórcio de capim-tanzânia com o estilosantes 'Campo Grande' pode ser uma alternativa interessante para a manutenção e o melhoramento das condições físicas do solo.
\end{abstract}

Termos para indexação: Panicum maximum, Stylosanthes, resistência do solo à penetração, taxa de lotação animal.

\section{Introduction}

Pastures cultivated with the cultivar 'Tanzânia-1' of Guinea grass (Megathyrsus maximus (Jacq. B.K. Simon \& Jacobs) (syn. Panicum maximum Jacq.) have been showing outstanding agronomic and nutritional traits to be incorporated into beef cattle systems when grazing systems are satisfactorily managed and fertilized (Lins et al., 2015; Pinheiro et al., 2015). The
Pesq. agropec. bras., Brasília, v.53, n.4, p.478-486, Apr. 2018 DOI: 10.1590/S0100-204X2018000400009 (c) $\mathbf{B Y}$ This is an open-access article distributed under the Creative Commons Attribution 4.0 International License 
fertilization of grass pastures, especially with nitrogen incorporation, plays an essential role for the productive system, since, when there is no restriction of other nutrients, $\mathrm{N}$ is the greatest contributor to productivity enhancement (Euclides et al., 2007).

However, the intercrop of grasses with legume species is considered an environmentally friendly alternative for $\mathrm{N}$ incorporation into the production system (Silva \& Saliba, 2007; Fidalski et al., 2008). Besides, this strategy reduces the production costs with soil fertilization containing this nutrient (Lins et al., 2015). Likewise, the intercrop of grasses and legumes can influence favorably the soil physical conditions due to crop synergy and the distinct attributes of growth and radicular system displayed by these species (Franchini et al., 2016).

The incorporation into the soil of the $\mathrm{N}$ mineral form or the plant intercropping is considered beneficial to pastures, and promote superior productivity to them. However, the forage production increase could lead to the adoption of an excessive animal stocking rate, which would negatively influence the soil physical conditions (Ferreira et al., 2010), besides negatively affecting the soil physical properties, mainly in the superficial layer, compromising the root growth (Beloni et al., 2016). This outcome is directly associated with the increase of soil penetration resistance (PR) (Sarmento et al., 2008; Beloni et al., 2016), soil bulk density (BD) (Veiga et al., 2014), and alterations of the soil porous system (Sarmento et al., 2008), and affects the soil water and air storage capacity under pasture. An inadequate management of grazing animals impacts on soil physical properties and may also result in the reduction of the vegetal cover (Sarmento et al., 2008), consequently decreasing the nutrient use by forage due to limited root growth.

Therefore, to provide a subsidy to the implementation of sustainable grazing systems, the following hypotheses were tested: the increase of animal stocking rate resulting from the increase of soil mineral fertilization with $\mathrm{N}$ has negative effects on soil physical condition; and the intercropping of grasses and legumes is an efficient alternative to promote improvements of the soil physical conditions.

The objective of this work was to evaluate the physical properties of a soil cultivated with 'Tanzânia' grass fertilized with mineral $\mathrm{N}$ or intercropped with the legume 'Campo Grande' (Stylosanthes spp.), subjected to continuous grazing and variable stocking rate in a three-year chronosequence.

\section{Materials and Methods}

The experiment was carried out in the municipality of Santo Inácio $\left(23^{\circ} 25^{\prime} \mathrm{S}, 51^{\circ} 57^{\prime} \mathrm{W}\right.$, at $410 \mathrm{~m}$ altitude), in the state of Paraná, Brazil. According to the Köppen-Geiger's classification, the dominant climate is $\mathrm{Cfa}$ (humid subtropical mesothermic). Climate data referring to the period between November 2008 and July 2011 are presented in Figure 1. The soil was identified as a Latossolo Vermelho distrófico, according to the Brazilian soil classification system (Santos et al., 2013). At the beginning of the experiment, the 0.0$0.2 \mathrm{~m}$ soil depth have shown the following physical and chemical attributes: $800 \mathrm{~g} \mathrm{~kg}^{-1}$ sand, $40 \mathrm{~g} \mathrm{~kg}^{-1}$ silt, and $160 \mathrm{~g} \mathrm{~kg}^{-1}$ clay; $\mathrm{pH}\left(\mathrm{H}_{2} \mathrm{O}\right) 6.4 ; 0 \mathrm{cmol}_{\mathrm{c}} \mathrm{dm}^{-3}$ exchangeable $\mathrm{Al}^{+3}(\mathrm{KCl} \mathrm{mol} \mathrm{L}) ; 1.85 \mathrm{cmol}_{\mathrm{c}} \mathrm{dm}^{-3} \mathrm{H}^{+}+$ $\mathrm{Al}^{3+}$ (potential acidity, SMP); $9.42 \mathrm{mg} \mathrm{dm}^{-3}$ available $\mathrm{P}$ (Mehlich-1); $1.39 \mathrm{cmol}_{\mathrm{c}} \mathrm{dm}^{-3}$ exchangeable $\mathrm{Ca}^{2+}(\mathrm{KCl}$ mol L-1); $0.47 \mathrm{cmol}_{\mathrm{c}} \mathrm{dm}^{-3} \mathrm{Mg}^{2+}\left(\mathrm{KCl} \mathrm{mol} \mathrm{L}^{-1}\right) ; 0.11 \mathrm{cmol}_{\mathrm{c}}$ $\mathrm{dm}^{-3}$ available $\mathrm{K}^{+}$(Mehlich-1); $1.97 \mathrm{cmol}_{\mathrm{c}} \mathrm{dm}^{-3}$ sum of bases; $3.82 \mathrm{cmol}_{\mathrm{c}} \mathrm{dm}^{-3}$ cation exchange capacity (CEC); $51.6 \%$ base saturation; and $6.11 \mathrm{~g} \mathrm{dm}^{-3}$ soil organic carbon (Walkley-Black).

In November of 2008, the experimental area, which had been used during several years as a Urochloa brizantha (syn. Brachiaria brizantha) pasture, was established. Afterwards, $8 \mathrm{~kg} \mathrm{ha}^{-1}$ 'Tanzânia' grass seed were sown with a leveling harrow, and were cultivated as a single crop, or intercropped with the 'Campo Grande' legume forage (80\% Stylosanthes capitata + $20 \%$ Stylosanthes macrocephala - with $3 \mathrm{~kg} \mathrm{ha}^{-1}$ seed sown right after 'Tanzânia' grass.

The experiment was carried out in a randomized complete block design, with split plots subdivided into the first (2009), second (2010), and third (2011) experimental years, to quantify the evolution of soil physical properties, in a three-year chronosequence, with three replicates. The treatments were: 'Tanzânia' and stylosanthes; 'Tanzânia' and fertilization with 75 $\mathrm{kg} \mathrm{ha}^{-1} \mathrm{~N}$; 'Tanzânia' and fertilization with $150 \mathrm{~kg} \mathrm{ha}^{-1}$ $\mathrm{N}$; 'Tanzânia' and fertilization with $225 \mathrm{~kg} \mathrm{ha}^{-1} \mathrm{~N}$, totaling 12 experimental units of 1 ha each.

Before starting the experiment, liming (dolomitic limestone) was carried out based on soil analysis, with incorporation by plowing and leveling at the $0.0-0.2$ 
$\mathrm{m}$ soil depth, in order to elevate the base saturation to $70 \%$. Phosphate maintenance fertilization with a single application was performed, using superphosphate (60 $\left.\mathrm{kg} \mathrm{ha}^{-1} \mathrm{P}_{2} \mathrm{O}_{5}\right)$ at the pasture establishment. Fertilizations of $\mathrm{N}\left(75,150\right.$, and $\left.225 \mathrm{~kg} \mathrm{ha}^{-1} \mathrm{~N}\right)$ and $\mathrm{K}\left(60 \mathrm{~kg} \mathrm{ha}^{-1}\right.$ $\mathrm{K}_{2} \mathrm{O}$ ) were annually applied and divided into three applications, in the following periods: November 2008, and January and March 2009, in the first year; October 2009, and January and March 2010, in the second year; and October 2010, and January and March 2011, in the third year. Urea and ammonium nitrate were used as nitrogen source [urea with $45 \% \mathrm{~N}$, in the first year, and ammonium nitrate containing $33 \% \mathrm{~N}$, in the second and third years, as well as $\mathrm{K}$ chloride $\left(60 \% \mathrm{~K}_{2} \mathrm{O}\right)$ as potassium source].

The pasture was managed using a continuous grazing method, with variable stocking rate, and it was measured weekly to maintain the grazing height between $0.40-0.45 \mathrm{~m}$. Nelore steers with mean initial body weight of $230 \pm 5 \mathrm{~kg}$ were employed for plant height maintenance and pasture management. Three test animals and regulating cattle were used per picket, which were placed or removed, depending on the pasture height, according to the put-and-take method (Mott \& Lucas, 1952). An area adjacent to the experimental zone, containing the same grass species, was available for the maintenance of the regulating animals.

Three-soil samplings were taken to evaluate the soil physical properties, at the end of the autumn season of each year: July 2009, in the first experimental year; August 2010, in the second year; and July 2011, in the third year. For each sampling, nine soil samples with undisturbed structure were collected (three from each experimental unity, at the $0.0,0.0-0.075$, and 0.075 $0.15 \mathrm{~m}$ soil depths), using $100 \mathrm{~cm}^{3}$ volumetric cores ( $0.05 \mathrm{~m}$ height $\times 0.05 \mathrm{~m}$ diameter), totaling 72 samples per trial. The excess soil was removed from each sample, and soil volume was considered equivalent to the core volume.

These samples were, then, saturated with water by capillarity per 48 hours. After saturation, the sample mass was determined, and the samples were subjected to matric potentials of -1 and $-10 \mathrm{kPa}$, using a tension table similar to that described by Ball \& Hunter (1988). After reaching the equilibrium, indicated by water drainage absence in the tension table, the sample mass was once again determined. Finally, the samples

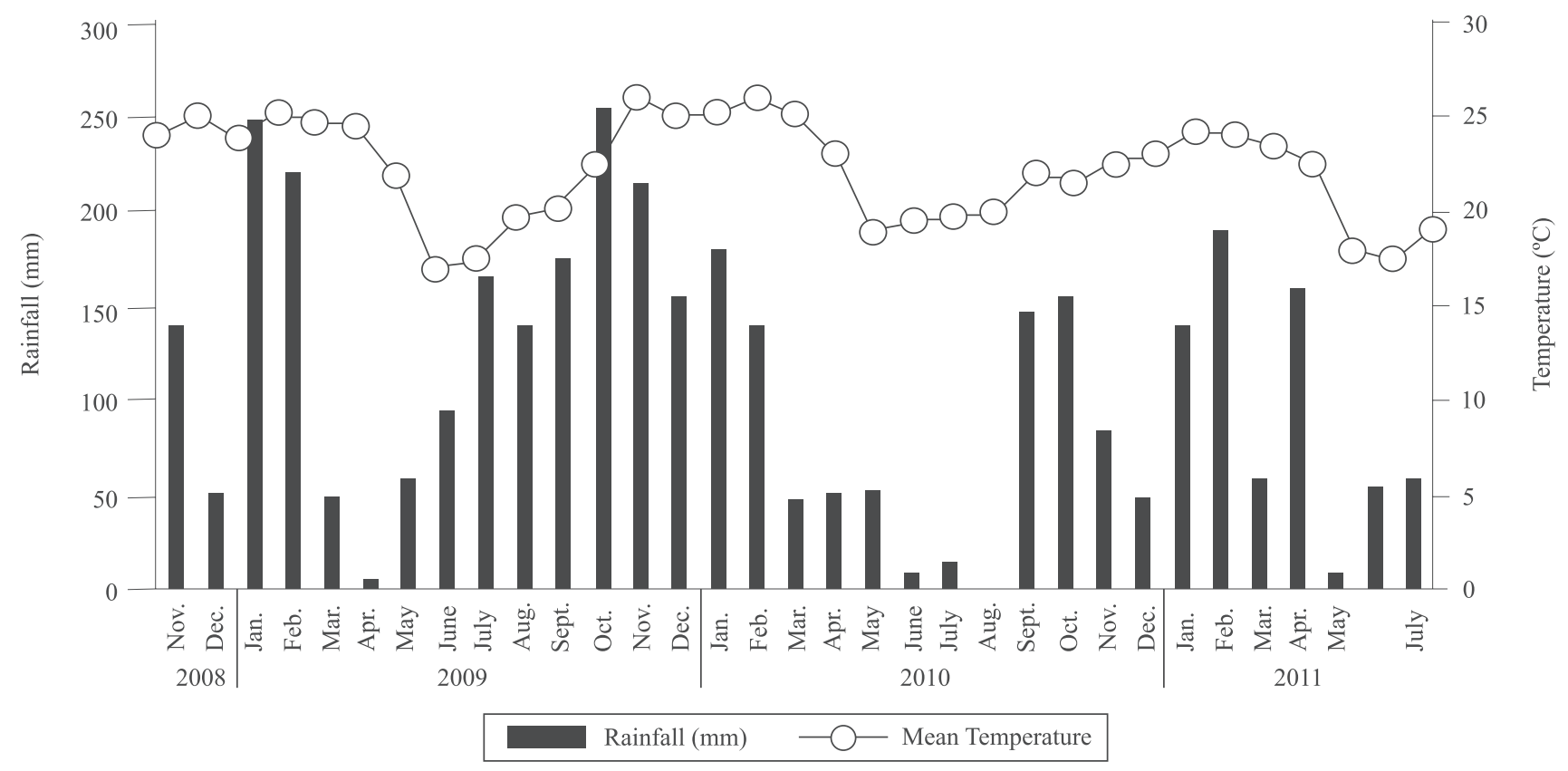

Figure 1. Temperature and rainfall values observed during the experimental period between November 2008 and July 2011. in the municipality of Santo Inácio, in the state of Paraná, Brazil. 
were dried in an oven at $\pm 105^{\circ} \mathrm{C}$ per 24 hours, and the sample mass was again measured. Porosity in the soil macropore domain, and soil water and air storage capacity were determined according to Reynolds et al. (2002), while BD was calculated according to Grossman \& Reinsch (2002).

The soil physical indices were obtained according to Reynolds et al. (2002), as follows: porosity in the soil macropore domain $\left(\mathrm{m}^{3} \mathrm{~m}^{-3}\right)$, obtained by subtracting the total porosity by the water content at $-1 \mathrm{kPa}$ matric potential, in which pores with diameter over $300 \mu \mathrm{m}$ are drained; soil water storage capacity indicator (dimensionless), calculated by the ratio between soil water content retained at the matric potential equivalent to field capacity $(-10 \mathrm{kPa})$ and total porosity; and soil air storage capacity indicator (dimensionless), calculated by the quotient between the pore drained volume in saturated soil, and field capacity in relation to total porosity.

Soil penetration resistance (PR) measurements were obtained every $0.01 \mathrm{~m}$ until $0.40 \mathrm{~m}$ soil depth, using a PLG 1020 penetrometer (Falker, Porto Alegre, $\mathrm{RS}$, Brazil). The measurements were performed two days after a sufficient rain occurrence, to moisten the sampled profile, so that the soil water content was assumed to be close to that of the field capacity. Five PR measurements were carried out for each experimental unity, adopting the value of $2,500 \mathrm{kPa}$ as restrictive to root growth, according to Imhoff et al. (2000). Samples were also collected to determine the soil water content $\left(\mathrm{kg} \mathrm{kg}^{-1}\right)$ at $0.0-0.1,0.1-0.2,0.2-0.3$, and $0.3-0.4 \mathrm{~m}$ soil depths; these samples were oven dried at $105^{\circ} \mathrm{C}$ for 24 hours. Water content was achieved by the ratio between water mass and the mass of soil solids.

Data of the soil physical properties (sample mean per experimental plot) among treatments and years have confirmed the hypothesis of homoscedasticity variances by the Levene test, at 5\% probability. Subsequently, data were subjected to the analysis of variance, in a randomized complete block design with split plots in periods of time, and the soil depths were compared separately. Means were compared by the Tukey's test, at $5 \%$ probability.

\section{Results and Discussion}

Treatments of 'Tanzânia' grass intercropped with stylosanthes 'Campo Grande', or fertilized with different $\mathrm{N}$ doses, have shown different forage dry mass between treatments, which, in turn, defined different animal stocking rates in the study period (Table 1).

The results have shown that $\mathrm{BD}$ and porosity in the soil macropore domain were not influenced by the treatments, regardless year and soil depths (Table 2). These results suggest that the $\mathrm{N}$ fertilization increment and the consequent increase of animal stocking rate (Table 1) have presented no impact on the soil physical properties during the experimental period. This fact may be associated with the grazing height maintenance between $0.40-0.45 \mathrm{~m}$, in the different treatments, which has probably contributed to minor animal crossings inside the experimental units, according to Baggio et al. (2009). These results are in accordance with Fidalski et al. (2008), who also came across no significant differences in these physical properties, when studying the effects of dissimilar $\mathrm{N}$ fertilizing doses $\left(0,100\right.$, and $\left.200 \mathrm{~kg} \mathrm{ha}^{-1}\right)$ on Coastcross grass (Cynodon dactylon) pastures intercropped, or not, with legume forage peanuts (Arachis pintoi). In contrast, Sarmento et al. (2008) have found that enhancing $\mathrm{N}$ doses contributed to $\mathrm{BD}$ increase until $214 \mathrm{~kg} \mathrm{ha}^{-1} \mathrm{~N}$ in pastures of Megathyrsus maximus 'IPR-86 Millennium'; such differences were attributed to the animal stocking rate, which was on average 2.6 AU ha ${ }^{-1}$, while Sarmento et al. (2008) obtained about $7 \mathrm{AU} \mathrm{ha}^{-1}$, which resulted in more elevated pressure applied on soil by animal hooves.

Table 1. Mean \pm standard deviation of Forage dry mass and animal stocking rate in 'Tanzânia' grass (Megathyrsus maximus) pasture intercropped with stylosanthes 'Campo Grande' (Stylosanthes spp.), or fertilized with different nitrogen doses $\left(75,150\right.$, and $\left.225 \mathrm{~kg} \mathrm{ha}^{-1} \mathrm{~N}\right)$ in the $1^{\text {st }}, 2^{\text {nd }}$, and $3^{\text {rd }}$ experimental years.

\begin{tabular}{cccccc}
\hline Year & Stylosanthes & $75 \mathrm{~kg} \mathrm{~N}$ & $150 \mathrm{~kg} \mathrm{~N}$ & $225 \mathrm{~kg} \mathrm{~N}$ & Mean \\
\hline \multicolumn{5}{c}{ Forage dry mass $\left(\mathrm{kg} \mathrm{ha}^{-1}\right)$} \\
$1^{\text {st }}$ & $2,349 \pm 87^{(1)}$ & $2,291 \pm 86$ & $2,441 \pm 92$ & $2,803 \pm 96$ & 2,471 \\
$2^{\text {nd }}$ & $4,401 \pm 528$ & $4,764 \pm 544$ & $5,244 \pm 603$ & $6,702 \pm 605$ & 5,278 \\
$3^{\text {rd }}$ & $4,584 \pm 546$ & $4,986 \pm 432$ & $5,508 \pm 452$ & $6,879 \pm 712$ & 5,489 \\
\hline \multicolumn{5}{c}{ Animal stocking rate $\left(\mathrm{AU} \mathrm{ha}^{-1}\right)$} \\
$1^{\text {st }}$ & $2.21^{(2)} \pm 0.11$ & $2.22 \pm 0.12$ & $2.28 \pm 0.11$ & $2.43 \pm 0.13$ & 2.31 \\
$2^{\text {nd }}$ & $2.26 \pm 0.14$ & $2.33 \pm 0.20$ & $2.62 \pm 0.33$ & $3.10 \pm 0.23$ & 2.58 \\
$3^{\text {rd }}$ & $2.10 \pm 0.12$ & $2.40 \pm 0.17$ & $2.70 \pm 0.11$ & $3.20 \pm 0.24$ & 2.60 \\
\hline
\end{tabular}

${ }^{(1)} \mathrm{AU}$, animal unity (1 $\mathrm{AU}=450 \mathrm{~kg}$ of body weight). 
In the $0.0-0.075 \mathrm{~m}$ soil depth, all treatments showed a BD increase from the first to the second experimental year. However, the treatments that received higher $\mathrm{N}$ doses (150 and $\left.225 \mathrm{~kg} \mathrm{ha}^{-1}\right)$ had a BD decrease in the third year. Therefore, the higher concentration of forage dry mass in these treatments (Table 1) may have protected the soil against animal trampling. Moreover, this elevated concentration provided a great organic matter input and root growth, avoiding soil compaction (Sarmento et al., 2008). These factors together may have contributed to BD reduction in these treatments.

Lower values of porosity in the soil macropore domain, in the second year, may explain why BD have reached the highest values in this year. Although there is no consensus regarding optimal values of porosity for macrospore domain (Reynolds et al., 2009), this variable enhancement is desirable, since porosity in the soil macropore domain comprises the pore volume

Table 2. Soil physical properties under 'Tanzânia' grass (Megathyrsus maximus) pasture intercropped with stylosanthes 'Campo Grande' (Stylosanthes spp.), or fertilized with different doses of nitrogen $(75,150$, and 225 $\mathrm{kg} \mathrm{ha}{ }^{-1} \mathrm{~N}$ ) in the $1^{\text {st }}, 2^{\text {nd }}$, and $3^{\text {rd }}$ experimental years.

\begin{tabular}{|c|c|c|c|c|c|c|}
\hline \multirow[t]{2}{*}{$\mathrm{N}$ doses } & \multicolumn{3}{|c|}{$0.0-0.075 \mathrm{~m}$} & \multicolumn{3}{|c|}{$0.075-0.15 \mathrm{~m}$} \\
\hline & $1^{\text {st }}$ & $2^{\text {nd }}$ & $3^{\text {rd }}$ & $1^{\text {st }}$ & $2^{\text {nd }}$ & $3^{\text {rd }}$ \\
\hline & \multicolumn{6}{|c|}{ Soil bulk density $\left(\mathrm{Mg} \mathrm{m}^{-3}\right)$} \\
\hline Styl. & $1.588 \mathrm{Aa}$ & $1.708 \mathrm{Ac}$ & $1.648 \mathrm{Ab}$ & $1.624 \mathrm{Aa}$ & $1.763 \mathrm{Ab}$ & $1.670 \mathrm{Aa}$ \\
\hline $75 \mathrm{~kg} \mathrm{~N}$ & $1.598 \mathrm{Aa}$ & $1.693 \mathrm{Ab}$ & $1.664 \mathrm{Ab}$ & $1.650 \mathrm{Aa}$ & $1.763 \mathrm{Ab}$ & $1.702 \mathrm{Aa}$ \\
\hline $150 \mathrm{~kg} \mathrm{~N}$ & $1.608 \mathrm{Aa}$ & $1.706 \mathrm{Ab}$ & $1.642 \mathrm{Aa}$ & $1.636 \mathrm{Aa}$ & $1.794 \mathrm{Ab}$ & $1.673 \mathrm{Aa}$ \\
\hline \multirow[t]{2}{*}{$225 \mathrm{~kg} \mathrm{~N}$} & $1.616 \mathrm{Aa}$ & $1.714 \mathrm{Ab}$ & $1.647 \mathrm{Aa}$ & $1.634 \mathrm{Aa}$ & $1.769 \mathrm{Ac}$ & $1.681 \mathrm{Ab}$ \\
\hline & \multicolumn{6}{|c|}{ Porosity in the soil macropore domain $\left(\mathrm{m}^{3} \mathrm{~m}^{-3}\right)$} \\
\hline Styl. & $0.026 \mathrm{Aa}$ & $0.017 \mathrm{Ab}$ & $0.027 \mathrm{Aa}$ & $0.026 \mathrm{Aa}$ & $0.017 \mathrm{Ab}$ & $0.025 \mathrm{Aa}$ \\
\hline $75 \mathrm{~kg} \mathrm{~N}$ & $0.023 \mathrm{Aa}$ & $0.017 \mathrm{Aa}$ & $0.023 \mathrm{Aa}$ & $0.023 \mathrm{Aab}$ & $0.017 \mathrm{Ab}$ & $0.026 \mathrm{Aa}$ \\
\hline $150 \mathrm{~kg} \mathrm{~N}$ & $0.024 \mathrm{Aab}$ & $0.018 \mathrm{Ab}$ & $0.026 \mathrm{Aa}$ & $0.022 \mathrm{Aa}$ & $0.014 \mathrm{Ab}$ & $0.03 \mathrm{Aa}$ \\
\hline \multirow[t]{2}{*}{$225 \mathrm{~kg} \mathrm{~N}$} & $0.025 \mathrm{Aa}$ & $0.017 \mathrm{Ab}$ & $0.026 \mathrm{Aa}$ & $0.020 \mathrm{Ab}$ & $0.015 \mathrm{Ab}$ & $0.028 \mathrm{Aa}$ \\
\hline & \multicolumn{6}{|c|}{ Soil water storage capacity } \\
\hline Styl. & $0.789 \mathrm{Ab}$ & $0.579 \mathrm{Aa}$ & $0.625 \mathrm{Aa}$ & $0.780 \mathrm{Ab}$ & $0.633 \mathrm{Aa}$ & $0.593 \mathrm{Aa}$ \\
\hline $75 \mathrm{~kg} \mathrm{~N}$ & $0.779 \mathrm{Ab}$ & $0.591 \mathrm{Aa}$ & $0.595 \mathrm{ABa}$ & $0.729 \mathrm{Ab}$ & $0.664 \mathrm{Aab}$ & $0.679 \mathrm{Aa}$ \\
\hline $150 \mathrm{~kg} \mathrm{~N}$ & $0.788 \mathrm{Ab}$ & $0.536 \mathrm{Aa}$ & $0.504 \mathrm{Ba}$ & $0.735 \mathrm{Ab}$ & $0.654 \mathrm{Aab}$ & $0.617 \mathrm{Aa}$ \\
\hline \multirow[t]{2}{*}{$225 \mathrm{~kg} \mathrm{~N}$} & $0.784 \mathrm{Ab}$ & $0.568 \mathrm{Aa}$ & $0.565 \mathrm{ABa}$ & $0.800 \mathrm{Ab}$ & $0.683 \mathrm{Aa}$ & $0.578 \mathrm{Aa}$ \\
\hline & \multicolumn{6}{|c|}{ Soil air storage capacity } \\
\hline Styl. & $0.211 \mathrm{Ab}$ & $0.421 \mathrm{Aa}$ & $0.375 \mathrm{Ba}$ & $0.219 \mathrm{Ab}$ & $0.367 \mathrm{Aa}$ & $0.407 \mathrm{Aa}$ \\
\hline $75 \mathrm{~kg} \mathrm{~N}$ & $0.221 \mathrm{Ab}$ & $0.409 \mathrm{Aa}$ & $0.405 \mathrm{ABa}$ & $0.270 \mathrm{Ab}$ & $0.336 \mathrm{Aab}$ & $0.321 \mathrm{Aa}$ \\
\hline $150 \mathrm{~kg} \mathrm{~N}$ & $0.212 \mathrm{Ab}$ & $0.464 \mathrm{Aa}$ & $0.496 \mathrm{Aa}$ & $0.265 \mathrm{Ab}$ & $0.346 \mathrm{Aab}$ & $0.383 \mathrm{Aa}$ \\
\hline $225 \mathrm{~kg} \mathrm{~N}$ & $0.216 \mathrm{Ab}$ & $0.432 \mathrm{Aa}$ & $0.434 \mathrm{ABa}$ & $0.200 \mathrm{Ab}$ & $0.317 \mathrm{Aa}$ & $0.422 \mathrm{Aa}$ \\
\hline
\end{tabular}

range, which is easily modified by management and is linked to the pores responsible for water infiltration into soil, in tensions close to saturation (Lanzanova et al., 2007).

In the first year, storage capacity values have shown a higher imbalance of water and air, at $0.0-0.75$ and $0.075-0.15 \mathrm{~m}$ soil depths, and they are distant from optimal values (Reynolds et al., 2002), with means adjacent to 0.80 of soil water storage capacity. Therefore, it would be necessary a soil drainage beyond field capacity, for plants to find adequate soil aeration conditions. In the $0.075-0.15 \mathrm{~m}$ soil depth, the treatments showed no significant differences in the assessed years (Table 2). Moreover, in this layer, these indices showed a similar behavior to the superior layer, denoting the more accentuated imbalances between water/air relations in the first year.

After three experimentation years, at the $0.0-0.75 \mathrm{~m}$ soil depth, the treatment in which 'Tanzânia' grass was fertilized with $150 \mathrm{~kg} \mathrm{ha}^{-1} \mathrm{~N}$ exhibited a minor capacity to retain water in the soil (0.51), and a major ability to maintain air in the soil (0.49). These values were distant from the ideal ones - recommended by Reynolds et al. (2002) - of 0.66 and 0.34 for storage capacity of water and air in the soil, respectively. These results indicate that there is a greater probability that the pasture may undergo water stress in treatments with applications of $150 \mathrm{~kg} \mathrm{ha}^{-1} \mathrm{~N}$ than in other treatments. However, soil in the treatment with Stylosanthes spp. showed a soil storage capacity rate of water and air close to the appropriate ones ( 0.62 and 0.38 , respectively), denoting a great soil physical condition for the forage production system. An increase of soil water storage capacity is essential for a sustainable pasture production in sandy soils of the Paraná northwest region.

It was possible to observe that, from the first to the second year, the forage yield doubled regardless of the treatment (Table 1), which shows an improvement of the soil physical conditions. This is evident by the indices of soil air and water storage capacity associated to the $\mathrm{N}$ fertilization management, which has enabled an increase of the animal stocking rate, without compromising the soil physical conditions. In addition, it can be highlighted that the pasture was still settling down in the first year.

In the third year, these values were maintained, promoting a productive and sustainable pastural system, even after three years. Fidalski et al. (2008) 
and Sarmento et al. (2008) have observed that, in similar soil and climatic conditions, the adequate pasture management has promoted the productive system even after five years of experimentation. In contrast, Franchini et al. (2016) observed, in analogous edaphoclimatic conditions, that yield and forage quality have decreased, even with animal stocking rate adjustment over time. However, the study was carried out in a crop-livestock integration system in which forage was sown after two years of grain production. Despite this fact, the same authors have also observed the benefits on the soil physical properties obtained with pasture cultivation and animal stocking rate adjustment. Therefore, it is noteworthy that pasture productivity and longevity vary depending on the adopted pasture management system and the edaphoclimatic conditions (Imhoff et al., 2000).

As to the values of soil penetration resistance (PR) and soil water content, the latter showed no difference between treatments in the three assessed years (Figure 2). Although the soil surface layer was the most affected by animal trampling impact, it had the lowest-PR values independently of the year, which indicates that the pasture management was efficient for every treatment used, considering that no significant differences were observed between treatments.

As previously mentioned, the vegetal cover maintenance (Table 1) could have minimized the animal trampling effect on the soil upper layer, which has been related to this cover reduction when the pasture is managed under direct grazing (Ferreira et al., 2010). Sarmento et al. (2008) found a comparable behavior in a study performed with Megathyrsus maximus.

This research results indicate that higher values of PR were found in the first year (Figure 2), when the $0.2-0.3 \mathrm{~m}$ soil depth showed the more elevated values of PR. In this layer, every treatments have shown a PR higher than the critical limit of 2,500 $\mathrm{kPa}$ (Imhoff et al., 2000), mainly the treatment that received $150 \mathrm{~kg}$ $\mathrm{N} \mathrm{ha}^{-1}$ that outstands for its observed PR $(4,293 \mathrm{kPa})$, which indicates the restrictive physical conditions to forage root growth. Since this soil layer exhibits reduced chances of being altered by animal trampling, the obtained results are attributed to a previous management of the area. In addition, even mechanical operations for the experiment implementation were not sufficient to promote such alterations.
In the second year, even with a minimal variation in soil water content, a considerable decrease of PR values was observed, mainly at $0.2-0.3 \mathrm{~m}$ soil depth. This behavior was maintained in the third year. This PR reduction could be resulted from positive effects of the vigorous radicular system of the forage grass on the soil structure (Alencar et al., 2010). Several authors have reported that the effective root system of 'Tanzânia' grass was superior at $0.3 \mathrm{~m}$ soil depth (Cunha et al., 2007, 2010; Alencar et al., 2010), which acts on the physical improvement of compacted layers from soil subsurface, improving the soil profile after the pasture establishment period. Franchini et al. (2016) conclusions indicate that this grass radicular system could reach depths superior to one meter, effectively contributing to positive alterations on the soil profile.

In general, the increase of animal stocking rate, through the mass increment and accumulation of forage with $\mathrm{N}$ fertilization, did not affect negatively the soil physical conditions evaluated by the indicators $\mathrm{BD}$ and porosity in the soil macropore domain, which were sensitive to differentiate uniquely the soil sampling years (Table 2). Beloni et al. (2016) have also verified that the highest-animal stocking rate, provided by $\mathrm{N}$ fertilization addition, did not affect the physical conditions of similar soils containing Megathyrsus maximus.

After three experimentation years, soil water and air storage capacity were the most sensitive variables to distinguish treatments and sampling years, indicating a greater imbalance between water/air ratio in the treatment that received $150 \mathrm{~kg} \mathrm{ha}^{-1} \mathrm{~N}$. Additionally, the intercrop use has proved to be a noticeable alternative for the maintenance of soil physical conditions, in pastures managed with direct grazing containing soil storage capacity values of both water and air close to the ideal ones recommended by Reynolds et al. (2002). The PR had a reduction of its values in depth from the second experimental year on, indicating an improvement of the soil profile.

\section{Conclusions}

1. The higher-animal stocking rate - due to the increased forage yield resulting from nitrogen fertilization - has no negative effects on the soil physical conditions for three years.

Pesq. agropec. bras., Brasília, v.53, n.4, p.478-486, Apr. 2018 DOI: 10.1590/S0100-204X2018000400009 

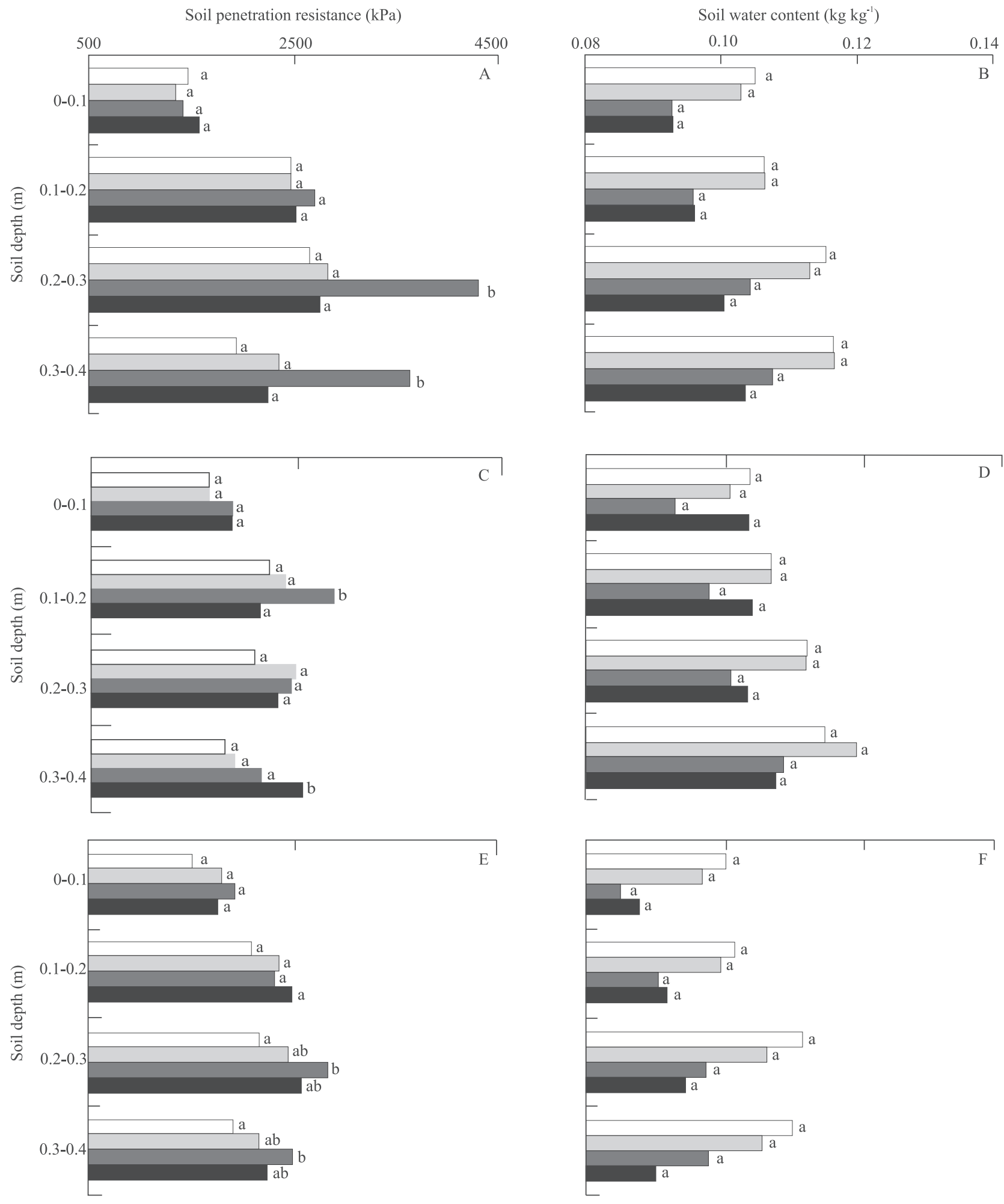

Figure 2. Soil penetration resistance (PR) (A, C, and E), and water content (B, D, and F) at the distinct soil depths under 'Tanzânia' grass (Megathyrsus maximus) intercropped with stylosanthes 'Campo Grande' (Stylosanthes spp.), or fertilized with nitrogen in the first (A and B), second (C and D) and third (E and F) experimental years. Means followed by equal letters, in the same depth, do not differ, by the Tukey's test, at $5 \%$ probability. 
2. 'Tanzânia' grass (Megathyrsus maximus) intercropped with stylosanthes 'Campo Grande' (Stylosanthes spp.) can be a remarkable alternative for the maintenance and improvement of the soil physical conditions.

\section{Acknowledgments}

To Conselho Nacional de Desenvolvimento Científico e Tecnológico (CNPq), for financial support.

\section{References}

ALENCAR, C.A.B. de; OLIVEIRA, R.A. de; CÓSER, A.C.; MARTINS, C.E.; FIGUEIREDO, J.L.A.; CUNHA, F.F. da. Produção de seis capins manejados por pastejo sob efeito de diferentes doses nitrogenadas e estações anuais. Revista Brasileira de Saúde e Produção Animal, v.11, p.48-58, 2010.

BAGgiO, C.; CARVAlHO, P.C. de F.; SILVA, J.L.S. da; ANGHINONI, I.; LOPES, M.L.T.; THUROW, J.M. Padrões de deslocamento e captura de forragem por novilhos em pastagem de azevém-anual e aveia-preta manejada sob diferentes alturas em sistema de integração lavoura-pecuária. Revista Brasileira de Zootecnia, v.38, p.215-222, 2009. DOI: 10.1590/S151635982009000200001 .

BALL, B.C.; HUNTER, R. The determination of water release characteristics of soil cores at low suctions. Geoderma, v.43, p.195-212, 1988. DOI: 10.1016/0016-7061(88)90043-2.

BELONI, T.; PIOTTO, V.C.; MARI, G.C.; PINHEIRO, A.A.; TORMENA, C.A.; CECATO, U. Root system and resistance to penetration of Mombaça grass fertilized with nitrogen and irrigated. Semina: Ciências Agrárias, v.37, p.3243-3252, 2016. DOI: $10.5433 / 1679-0359.2016 \mathrm{v} 37 \mathrm{n} 5 \mathrm{p} 3243$.

CUNHA, F.F. da; RAMOS, M.M.; ALENCAR, C.A.B. de; MARTINS, C.E.; CÓSER, A.C.; OLIVEIRA, R.A. de. Sistema radicular de seis gramíneas irrigadas em diferentes adubações nitrogenadas e manejos. Acta Scientiarum. Agronomy, v.32, p.351-357, 2010. DOI: 10.4025/actasciagron.v32i2.1020.

CUNHA, F.F. da; SOARES, A.A.; SEDIYAMA, G.C.; MANTOVANI, E.C.; PEREIRA, O.G.; ABREU, F.V. de S.; SOUZA, D.O. Avaliação do sistema radicular do capim-tanzânia submetido a diferentes níveis de irrigação e turnos de rega. Engenharia na Agricultura, v.15, p.200-211, 2007.

EUCLIDES, V.P.B.; MACEDO, M.C.M.; ZIMMER, A.H.; MEDEIROS, R.N. de; OLIVEIRA, M.P. de. Características do pasto de capim-tanzânia adubado com nitrogênio no final do verão. Pesquisa Agropecuária Brasileira, v.42, p.1189-1198, 2007. DOI: 10.1590/S0100-204X2007000800017.

FERREIRA, R.R.M.; TAVARES FILHO, J.; FERREIRA, V.M. Efeitos de sistemas de manejo de pastagens nas propriedades físicas do solo. Semina: Ciências Agrárias, v.31, p.913-932, 2010. DOI: 10.5433/1679-0359.2010v31n4p913.

FIDALSKI, J.; TORMENA, C.A.; CECATO, U.; BARBERO, L.M.; LUGÃO, S.M.B.; COSTA, M.A.T. Qualidade física do solo em pastagem adubada e sob pastejo contínuo. Pesquisa Agropecuária Brasileira, v.43, p.1583-1590, 2008. DOI: 10.1590/ S0100-204X2008001100018.

FRANCHINI, J.C.; VELLINI, C.L.; BALBINOT JR., A.A.; DEBIASI, H.; WATANABE, R.H. Integração Lavoura-Pecuária em solo arenoso e clima quente: duas décadas de experiência. Londrina: Embrapa Soja, 2016. (Embrapa Soja. Circular técnica, 118).

GROSSMAN, R.B.; REINSCH, T.G. Bulk density and linear extensibility. In: DANE, J.H.; TOPP, G.C. (Ed.). Methods of soil analysis: part 4: Physical methods. Madison: Soil Science Society of America, 2002. p.201-228.

IMHOFF, S.; SILVA, A.P. da; TORMENA, C.A. Aplicações da curva de resistência no controle da qualidade física de um solo sob pastagem. Pesquisa Agropecuária Brasileira, v.35, p.1493-1500, 2000. DOI: 10.1590/S0100-204X2000000700025.

LANZANOVA, M.E.; NICOLOSO, R. da S.; LOVATO, T.; ELTZ, F.L.F.; AMADO, T.J.C.; REINERT, D.J. Atributos físicos do solo em sistema de integração lavoura-pecuária sob plantio direto. Revista Brasileira de Ciência do Solo, v.31, p.1131-1140, 2007. DOI: $10.1590 / \mathrm{S} 0100-06832007000500028$.

LINS, T.O.J.D'A.; CECATO, U.; PINHEIRO, A.A.; IWAMOTO, B.S.; KRUTZMANN, A.; BELONI, T.; SILVA, R.R. Características morfogênicas do capim-Tanzânia consorciado com Estilosantes Campo Grande ou adubado com nitrogênio sob pastejo. Semina: Ciências Agrárias, v.36, p.2739-2752, 2015. DOI: $10.5433 / 1679-0359.2015 v 36 n 4 p 2739$.

MOTT, G.O.; LUCAS, H.L. The design, conduct, and interpretation of grazing trials on cultivated and improved pastures. In: INTERNATIONAL GRASSLAND CONGRESS, 6., 1952, Pennsylvania. Proceedings. Pennsylvania: State College Press, 1952. p.1380-1385.

PINHEIRO, A.A.; CECATO, U.; LINS, T.O.J.D'A.; BELONI, T.; KRUTZMANN, A.; IWAMOTO, B.S.; MARI, G.C. Acúmulo e composição morfológica do pasto de capim-tanzânia adubado com nitrogênio ou consorciado com estilosantes Campo Grande. Bioscience Journal, v.31, p.850-858, 2015. DOI: 10.14393/BJv31n3a2015-22013.

REYNOLDS, W.D.; BOWMAN, B.T.; DRURY, C.F.; TAN, C.S.; LU, X. Indicators of good soil physical quality: density and storage parameters. Geoderma, v.110, p.131-146, 2002. DOI: 10.1016/S0016-7061(02)00228-8.

REYNOLDS, W.D.; DRURY, C.F.; TAN, C.S.; FOX, C.A.; YANG, $\mathrm{X} . \mathrm{M}$. Use of indicators and pore volume-function characteristics to quantify soil physical quality. Geoderma, v.152, p.252-263, 2009. DOI: 10.1016/j.geoderma.2009.06.009.

SANTOS, H.G. dos; JACOMINE, P.K.T.; ANJOS, L.H.C. dos; OLIVEIRA, V.A. de; LUMBRERAS, J.F.; COELHO, M.R.; ALMEIDA, J.A. de; CUNHA, T.J.F.; OLIVEIRA, J.B. de. Sistema brasileiro de classificação de solos. 3.ed. rev. e ampl. Brasília: Embrapa, 2013. 353p.

SARMENTO, P.; RODRIGUES, L.R. de A.; CRUZ, M.C.P. da; LUGÃO, S.M.B.; CAMPOS, F.P. de; CENTURION, J.F.; FERREIRA, M.E. Atributos químicos e físicos de um Argissolo cultivado com Panicum maximum Jacq. cv. IPR-86 Milênio, sob lotação rotacionada e adubado com nitrogênio. Revista Brasileira 
de Ciência do Solo, v.32, p.183-193, 2008. DOI: 10.1590/S010006832008000100018.

SILVA, J.J. da; SALIBA, E. de O.S. Pastagens consorciadas: uma alternativa para sistemas extensivos e orgânicos. Veterinária e Zootecnia, v.14, p.8-18, 2007.
VEIGA, M. da; BALBINOT JUNIOR, A.A.; OLIVEIRA, D.A. de. Soil physical attributes in forms of sowing the annual winter pasture and intervals between grazing. Revista Ciência Agronômica, v.45, p.896-905, 2014. Número especial. DOI: 10.1590/S1806-66902014000500005.

Received on February 10, 2017 and accepted on July 27, 2017 